\title{
HUBUNGAN PENGETAHUAN IBU DENGAN STATUS GIZI BALITA PADA MASA PANDEMI COVID-19 DI POSYANDU BLOK CIPEUCANG II DESA TALAGAWETAN UPTD PUSKESMAS TALAGA KABUPATEN MAJALENGKA TAHUN 2021
}

Yeti Yuwansyah, Ayu Idaningsih, Farida Fitriani

STIKes YPIB Majalengka

yetiyuwansyah@gmail.com

\begin{abstract}
Abstrak
Kesehatan anak merupakan salah satu prioritas dalam pembangunan kesehatan suatu bangsa, terutama di masa pandemi Covid-19. Blok Cipeucang II Desa Talagawetan UPTD Puskesmas Talaga Kabupaten pada tahun 2020 merupakan salah satu blok dengan balita yang mengalami gizi buruk paling tinggi yaitu sebanyak 4 balita $(4,9 \%)$ dan balita yang gizi kurang sebanyak 14 balita (17,2\%). Penelitian ini bertujuan untuk mengetahui hubungan pengetahuan ibu dengan status gizi balita pada masa pandemi Covid-19 di Posyandu Blok Cipeucang II Desa Talagawetan UPTD Puskesmas Talaga Kabupaten Majalengka tahun 2021.

Penelitian yang digunakan adalah penelitian kuantitatif dengan desain cross sectional. Jumlah sampelnya adalah seluruh ibu yang mempunyai anak balita di Posyandu Blok Cipeucang Desa Talagawetan UPTD Puskesmas Talaga Kabupaten Majalengka sebanyak 90 orang (total sampling). Penelitian ini telah dilaksanakan pada bulan April-Mei 2021. Analisis univariat menggunakan distribusi frekuensi dan analisis bivariatnya dengan uji chi square.

Hasil penelitian menunjukkan bahwa sebagian kecil $(21,1 \%)$ status gizi balita pada masa pandemi Covid-19 adalah gizi kurang dan kurang dari setengah $(33,3 \%)$ ibu balita adalah berpengetahuan kurang baik. Ada hubungan pengetahuan Ibu dengan Status Gizi Balita pada Masa Pandemi Covid-19 di Posyandu Blok Cipeucang II Desa Talagawetan UPTD Puskesmas Talaga Kabupaten Majalengka tahun 2021 ( $\rho$ value = 0,037).

Upaya untuk mencegah gangguan gizi pada balita, maka petugas kesehatan bekerja sama dengan kader untuk melaksanakan kegiatan posyandu secara rutin setiap bulan, memotivasi ibu untuk membawa anaknya ditimbang ke posyandu, memberikan penyuluhan kepada ibu untuk memberikan makanan kepada anak sesuai jumlah, jadwal dan jenisnya.
\end{abstract}




\section{Pendahuluan}

Kesehatan anak merupakan salah satu prioritas dalam pembangunan kesehatan suatu bangsa, terutama di masa pandemi covid-19 yang mengakibatkan keterbatasan pelayanan kesehatan termasuk pada anak. Pandemi Covid-19 adalah situasi penyebaran penyakit yang diakibatkan oleh virus corona menyebar luas hampir ke seluruh negara di dunia. Virus corona adalah kelompok besar virus yang menyebabkan berbagai jenis penyakit. Mulai dari batuk pilek hingga penyakit yang lebih parah (Kementerian Kesehatan RI, 2020).

Kesehatan anak termasuk ke dalam salah satu indikator yang dapat menggambarkan kesejahteraan masyarakat di suatu negara. Kesehatan anak itu sendiri ditentukan oleh angka kematian, angka kesakitan, status gizi dan angka harapan hidup waktu lahir. Status gizi menjadi bagian yang sangat penting dalam menentukan derajat kesehatan anak. Status gizi yang baik dapat membantu proses pertumbuhan dan perkembangan anak untuk mencapai kematangan yang optimal (Kementerian Kesehatan RI, 2020).

Masalah gizi pada anak terutama balita perlu ditangani dengan baik karena berpotensi terhadap tingginya angka kematian. Menurut World Health Organization (WHO) menyatakan bahwa lebih dari separuh kematian bayi dan balita disebabkan oleh keadaan gizi. Anak yang mengalami kekurangan gizi memiliki resiko meninggal 13 kali lebih besar dibandingkan anak yang normal. WHO memperkirakan 54\% penyebab kematian bayi dan balita didasari oleh keadaan kurang gizi. Sementara menurut The United Nations Children's Fund (UNICEF) pada tahun 2016, diperkirakan 165 juta anak usia dibawah lima tahun di seluruh dunia mengalami gizi buruk (United Nations Children's Fund, 2017).

Gizi kurang dan gizi buruk merupakan status gizi yang didasarkan pada indeks berat badan menurut umur $(\mathrm{BB} / \mathrm{U})$. Pada balita usia 0-59 bulan, menurut laporan (Kementerian Kesehatan RI, 2020) persentase gizi buruk di Indonesia adalah 
JOURNAL OF MIDWIFERY CARE :

VOL. 02 No. 01, DESEMBER 2021

DOI: $\underline{10.34305 / J M C . V 2 I 01.356}$
3,9\%, sedangkan persentase gizi kurang adalah 13,8\% dengan jumlah balita secara nasional tercatat sebanyak 23.604.923 balita dan jumlah posyandu sebanyak 296.777 unit (Kementerian Kesehatan RI, 2020).

Prevalensi balita gizi buruk dan gizi kurang di Provinsi Jawa Barat yaitu untuk balita gizi buruk sebesar 2,60\% dan gizi kurang yaitu 10,60\% dengan jumlah balita sebanyak 4.326.811 balita dan jumlah posyandu sebanyak 51.306 unit (Kementerian Kesehatan RI, 2020). Adapun di Kabupaten Majalengka, berdasarkan data Dinas Kesehatan Kabupaten Majalengka tahun 2019, dari jumlah 88.139 balita, yang mengalami gizi kurang sebanyak 3.905 balita (4,43\%) dan gizi buruk sebanyak 737 balita $(0,84 \%)$. Jumlah posyandu tercatat sebanyak 650 unit. Sedangkan pada tahun 2020 dari jumlah 99.116 balita, yang mengalami gizi kurang sebanyak 4.511 balita (4,55\%) dan gizi buruk sebanyak 987 balita $(0,99 \%)$. Jumlah posyandu tercatat sebanyak 669 unit (Dinas Kesehatan Kabupaten Majalengka, 2020).

Jumlah balita di UPTD Puskesmas Talaga tahun 2020 ditimbang sebanyak 2.819 anak dan yang mengalami gizi buruk sebanyak 56 balita (1,98\%), gizi kurang sebanyak 212 balita (7,5\%), sementara jumlah posyandu yang aktif sebanyak 33 unit. Angka ini mengalami kenaikan dibanding dengan data pada tahun 2019, diketahui jumlah balita yang ditimbang sebanyak 3.343 anak dan yang mengalami gizi buruk sebanyak 40 balita $(1,06 \%)$, gizi kurang sebanyak 153 balita (4,04\%), normal sebanyak 3.063 balita $(80,88 \%)$ dan lebih sebanyak 87 balita, sementara jumlah posyandu yang aktif sebanyak 32 unit. Berdasarkan data tersebut kejadian gizi buruk dan kurang di UPTD Puskesmas Talaga tahun 2019-2020 mengalami kenaikan yaitu gizi buruk pada tahun 2019 sebesar $1,06 \%$ menjadi $1,98 \%$ di tahun 2020 .

Tingginya kejadian gizi buruk maupun gizi kurang pada masa pandemi ini perlu mendapatkan perhatian. Disamping karena kebijakan pembatasan sosial dan banyaknya aktivitas atau pekerjaan terhenti menyebabkan ekonomi lumpuh menjadi salah satu alasan pemenuhan kebutuhan keluarga menjadi terhambat pada masa pandemi ini (Ariesta, 2020). Menurut Hidayat (2018), gangguan gizi pada balita dapat dipengaruhi oleh penyebab langsung dan tidak langsung. 
JOURNAL OF MIDWIFERY CARE :

VOL. 02 No. 01, DESEMBER 2021

DOI: $10.34305 / \mathrm{JMC} . \mathrm{V} 2 \mathrm{I} 01.356$

Promosi kesehatan menjadi sangat penting dilakukan oleh petugas kesehatan di masa pandemi ini. Melalui kegiatan promosi kesehatan dapat meningkatkan pengetahuan ibu balita tentang gizi sehingga pada masa pandemi ini, ibu balita berusaha melakukan pemenuhan gizi pada anaknya sesuai dengan keadaan atau pembatasan sosial yang terjadi (Kementerian Kesehatan RI, 2020). Pengetahuan tentang gizi sangat diperlukan agar dapat mengatasi masalah-masalah yang timbul akibat konsumsi gizi. Wanita khususnya ibu sebagai orang yang bertanggung jawab terhadap konsumsi makanan bagi keluarga. Ibu harus memiliki pengetahuan tentang gizi baik diperoleh melalui pendidikan formal maupun non formal (Hardinsyah \& Supariasa, 2016).

Pengetahuan ibu balita tentang gizi sangat penting agar ibu mampu memberikan yang terbaik baik anakanaknya. Seorang ibu rumah tangga harus memiliki pengetahuan dalam menyusun dan menilai hidangan yang memenuhi syarat gizi, agar balita yang akan mengkonsumsinya tertarik serta pertumbuhan dan perkembangannya baik (Hardinsyah \& Supariasa, 2016).
Akbar \& Aidha (2020) di Kota Binjai Pada Masa Pandemi Covid-19 menunjukkan bahwa 30\% responden tidak paham tentang gizi seimbang untuk balita masa pandemi covid-19. Adapun penelitian yang dilakukan Puspasari \& Andriani (2017) menunjukkan bahwa ada hubungan antara pengetahuan ibu tentang gizi dan asupan makan balita dengan status gizi balita usia 12-24 bulan. Juga penelitian yang dilakukan oleh Harikatang \& Mardiyono (2020) di Satu Kelurahan di Tangerang menunjukkan bahwa ada hubungan antara pengetahuan dengan gizi balita.

Salah satu desa di wilayah kerja UPTD Puskesmas Talaga Kabupaten Majalengka tahun 2020 dengan angka kejadian gizi buruk paling tinggi yaitu sebanyak 7 balita $(3,4 \%)$ dan gizi kurang sebanyak 34 balita $(16,6 \%)$ dari jumlah balita sebanyak 204 balita. Desa Talagawetan terdiri dari delapan blok. Dari delapan blok tersebut yang paling banyak balita mengalami gizi buruk terdapat di Blok Cipeucang II sebanyak 4 balita (4,9\%) dan yang gizi kurang sebanyak 14 balita $(17,2 \%)$ dari jumlah balita sebanyak 81 balita. Hasil studi pendahuluan yang dilakukan peneliti di Posyandu Blok 
Cipeucang terhadap $10 \mathrm{ibu}$ balita dengan metode wawancara dengan hasil sebanyak 7 ibu balita belum mengerti mengenai makanan yang baik untuk anak balita serta dampaknya, sementara 3 ibu balita mengerti mengenai makanan yang baik bagi anaknya diantaranya ibu mengerti pentingnya makanan yang beraneka ragam dengan gizi seimbang dan diberikan setiap hari minimal 3 kali. Faktor lain yang juga mempengaruhi status gizi yaitu pendidikan, karena di lokasi penelitian masih banyak

\section{Metode}

Penelitian yang digunakan adalah penelitian kuantitatif dengan desain cross sectional. Sampel pada penelitian ini karena jumlah populasi $<100$ maka jumlah sampelnya adalah seluruh ibu yang mempunyai anak balita di Posyandu Blok Cipeucang Desa Talagawetan UPTD Puskesmas Talaga Kabupaten Majalengka sebanyak 90 orang (total sampling). yang berpendidikan rendah dan ekonomi yang disebabkan karena pandemi banyak yang tidak bekerja sehingga tidak mampu memenuhi kebutuhan gizi untuk balita. Berdasarkan latar belakang tersebut, maka peneliti tertarik melakukan penelitian mengenai "Hubungan pengetahuan ibu dengan status gizi balita pada masa pandemi Covid-19 di Posyandu Blok Cipeucang II Desa Talagawetan UPTD Puskesmas Talaga Kabupaten Majalengka tahun

$2021 \%$.

\section{Hasil}

1. Analisis Univariat

Tabel 1. Distribusi Frekuensi Status Gizi Balita pada Masa Pandemi Covid-19 di Posyandu Blok Cipeucang II Desa Talagawetan UPTD Puskesmas Talaga Kabupaten Majalengka tahun 2021 


\begin{tabular}{|c|c|c|}
\hline Status Gizi Balita pada Masa Pandemi Covid-19 & $\begin{array}{l}\text { Frekuensi } \\
\text { (F) }\end{array}$ & $\begin{array}{c}\text { Persen } \\
(\%)\end{array}$ \\
\hline Gizi buruk & 0 & 0 \\
\hline Gizi kurang & 19 & 21.1 \\
\hline Gizi lebih & 7 & 7.8 \\
\hline Gizi normal & 64 & 71.1 \\
\hline Total & 90 & $\mathbf{1 0 0 . 0}$ \\
\hline
\end{tabular}

Berdasarkan tabel 1, menunjukkan Posyandu Blok Cipeucang II Desa

bahwa sebagian kecil (21,1\%) status gizi Talagawetan UPTD Puskesmas Talaga balita pada masa pandemi Covid-19 di Kabupaten Majalengka adalah gizi kurang.

a. Gambaran Pengetahuan Ibu

Tabel 2. Distribusi Frekuensi Pengetahuan Ibu di Posyandu Blok Cipeucang II Desa Talagawetan UPTD Puskesmas Talaga Kabupaten Majalengka tahun 2021

\begin{tabular}{|c|c|c|c|}
\hline Pengetahuan Ibu & $\begin{array}{c}\text { Frekuensi } \\
\text { (F) }\end{array}$ & $\begin{array}{c}\text { Persen } \\
(\%)\end{array}$ & \\
\hline Kurang baik & 30 & 33.3 & \\
\hline Cukup & 37 & 41.1 & \\
\hline Baik & 23 & 25.6 & \\
\hline Total & 90 & 100.0 & \\
\hline Berdasarkan tabel 2, menunjukkan & Talagawetan & UPTD Puskesmas & Talaga \\
\hline bahwa kurang dari setengah $(33,3 \%)$ ibu & Kabupaten & Majalengka & adalah \\
\hline
\end{tabular}

2. Analisis Bivariat

a. Hubungan Pengetahuan Ibu dengan Status Gizi Balita pada Masa Pandemi Covid-19

Tabel 3. Hubungan Pengetahuan Ibu dengan Status Gizi Balita pada Masa Pandemi Covid-19 di Posyandu Blok Cipeucang II Desa Talagawetan UPTD Puskesmas Talaga Kabupaten Majalengka tahun 2021

\begin{tabular}{|c|c|c|c|c|c|c|c|c|c|c|}
\hline \multirow{3}{*}{ No } & \multirow{3}{*}{$\begin{array}{c}\text { Pengetahuan } \\
\text { Ibu }\end{array}$} & \multicolumn{6}{|c|}{$\begin{array}{c}\text { Status Gizi Balita pada Masa } \\
\text { Pandemi Covid-19 }\end{array}$} & \multirow{2}{*}{\multicolumn{2}{|c|}{ Jumlah }} & \multirow{2}{*}{ Jvalue } \\
\hline & & \multicolumn{2}{|c|}{$\begin{array}{c}\text { Gizi } \\
\text { kurang }\end{array}$} & \multicolumn{2}{|c|}{$\begin{array}{c}\text { Gizi } \\
\text { Lebih } \\
\end{array}$} & \multicolumn{2}{|c|}{$\begin{array}{c}\text { Gizi } \\
\text { Normal } \\
\end{array}$} & & & \\
\hline & & $\mathbf{N}$ & $\%$ & $\mathbf{N}$ & $\%$ & $\mathbf{N}$ & $\%$ & $\mathbf{N}$ & $\%$ & \multirow{4}{*}{0,037} \\
\hline 1 & Kurang & 12 & 40,0 & 1 & 3,3 & 17 & 56,7 & 30 & 100 & \\
\hline 2 & Cukup & 4 & 10,8 & 4 & 10,8 & 29 & 78,4 & 37 & 100 & \\
\hline 3 & Baik & 3 & 13,0 & 2 & 8,7 & 18 & 78,3 & 23 & 100 & \\
\hline
\end{tabular}




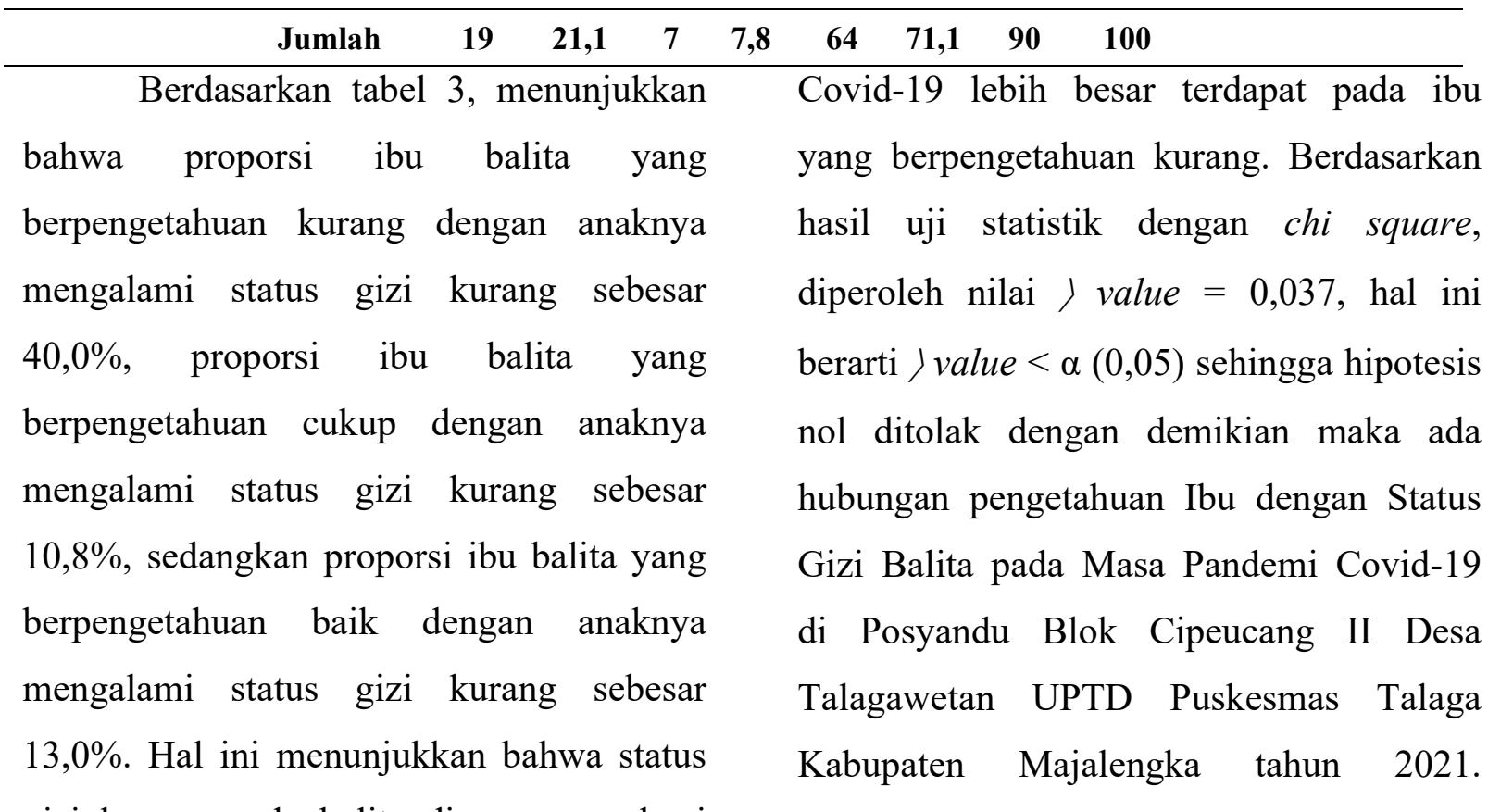
gizi kurang pada balita di masa pandemi

\section{Pembahasan}

Berdasarkan hasil penelitian menunjukkan bahwa sebagian kecil $(21,1 \%)$ status gizi balita pada masa pandemi Covid-19 di Posyandu Blok Cipeucang II Desa Talagawetan UPTD Puskesmas Talaga Kabupaten Majalengka adalah gizi kurang. Gizi kurang pada balita di masa pandemi Covid-19 dapat dikarenakan beberapa yaitu karena keterbatasan pelayanan akibat adanya pandemi dan juga ibu kurang memperhatikan kebutuhan gizi pada anaknya akibatnya anak mengalami gizi kurang.
Posyandu Blok Cipeucang II merupakan salah satu posyandu yang berada di Desa Talagawetan. Desa Talagawetan sendiri terdiri dari delapan blok. Dari delapan blok tersebut yang paling banyak balita mengalami gizi buruk terdapat di Blok Cipeucang II sebanyak 4 balita $(4,9 \%)$ dan yang gizi kurang sebanyak 14 balita $(17,2 \%)$ dari jumlah balita sebanyak 81 balita. Ibu balita di wilayah kerja Posyandu Blok Cipeucang II sebagian besar adalah ibu rumah tangga sebesar $80 \%$, ibu yang bekerja sebagai petani $(15 \%)$ dan pedagang sebanyak $5 \%$. Sebagian besar pendidikan ibu adalah SMP 
JOURNAL OF MIDWIFERY CARE :

VOL. 02 No. 01, DESEMBER 2021

DOI: $10.34305 / \mathrm{JMC} . \mathrm{V} 2 \mathrm{I} 01.356$ sebesar 45\% dan diikuti yang berpendidikan SD sebesar 23,5\%, SMA sebesar $15 \%$, pendidikan tinggi sebesar 5\% dan sisanya tidak sekolah (2,5\%). Hasil penelitian ini sejalan dengan penelitian yang dilakukan oleh Puspasari \& Andriani (2017) di Kecamatan Bantarkalong Tasikmalaya menunjukkan bahwa gizi balita usia 12-24 bulan dengan status gizi kurang sebesar 20,2\%. Juga sejalan dengan penelitian yang dilakukan oleh Harikatang \& Mardiyono (2020) di Tangerang menunjukkan bahwa balita yang mengalami gizi kurang sebesar 25,5\%. Gizi kurang pada balita di masa pandemi ini perlu mendapatkan perhatian. Disamping karena kebijakan pembatasan sosial dan banyaknya aktivitas atau pekerjaan terhenti menyebabkan ekonomi lumpuh menjadi salah satu alasan pemenuhan kebutuhan keluarga menjadi terhambat pada masa pandemi ini (Ariesta, 2020). Menurut Hidayat (2018), gangguan gizi pada balita dapat dipengaruhi oleh penyebab langsung dan tidak langsung. Penyebab langsung yaitu konsumsi makanan dan penyakit infeksi yang mungkin diderita anak. Penyebab tidak langsung yaitu pendapatan keluarga, jumlah anggota keluarga, pendidikan $\mathrm{ibu}$, pengetahuan $\mathrm{ibu}$, riwayat pemberian ASI, pemberian makanan tambahan, berat badan saat lahir dan kelengkapan imunisasi. Status gizi gizi baik dapat membantu proses pertumbuhan dan perkembangan anak untuk mencapai kematangan yang optimal (Kementerian Kesehatan RI, 2020). Masalah gizi pada anak terutama balita perlu ditangani dengan baik karena berpotensi terhadap tingginya angka kematian. Menurut World Health Organization (WHO) menyatakan bahwa lebih dari separuh kematian bayi dan balita disebabkan oleh keadaan gizi. Anak yang mengalami kekurangan gizi memiliki resiko meninggal 13 kali lebih besar dibandingkan anak yang normal (United Nations Children's Fund, 2017).

Sebagian kecil status gizi balita pada masa pandemi Covid-19 di Posyandu Blok Cipeucang II Desa Talagawetan UPTD Puskesmas Talaga Kabupaten Majalengka adalah gizi kurang. Maka upaya yang perlu dilakukan oleh ibu balita adalah dengan lebih aktif mencari informasi baik melalui media atau berkonsultasi dengan petugas kesehatan mengenai gizi yang baik bagi pertumbuhan dan perkembangan balita. Bagi petugas kesehatan perlunya memberikan edukasi dan penyuluhan kepada ibu balita di masa 
JOURNAL OF MIDWIFERY CARE :

VOL. 02 No. 01, DESEMBER 2021

DOI: $10.34305 / \mathrm{JMC} . \mathrm{V} 2 \mathrm{I} 01.356$ pandemi ini dengan memperhatikan protokol kesehatan Covid-19 dan perlunya di posyandu untuk melaksanakan kegiatan posyandu sesuai dengan protokol kesehatan Covid-19, menyediakan sarana cuci tangan dan alat pengukur suhu bagi yang berkunjung ke posyandu.

Berdasarkan hasil penelitian menunjukkan bahwa kurang dari setengah $(33,3 \%)$ ibu balita di Posyandu Blok Cipeucang II Desa Talagawetan UPTD Puskesmas Talaga Kabupaten Majalengka adalah berpengetahuan kurang baik. Pengetahuan tentang gizi balita di masa pandemi ini sangat penting dan ibu yang pengetahuannya kurang dapat mengakibatkan kurang memperhatikan gizi yang dibutuhkan oleh anaknya sehingga anak akan mengalami gangguan gizi. Pengetahuan ibu di lokasi penelitian masih banyak yang kurang hal ini dapat dikarenakan masih banyak ibu yang kurang aktif mencari informasi atau berkonsultasi kepada petugas kesehatan sehingga informasi yang didapat ibu tentang gizi masih kurang. Hasil penelitian ini sedikit lebih tinggi dibanding dengan hasil penelitian Akbar \& Aidha (2020) menunjukkan bahwa 30\% responden tidak paham tentang gizi seimbang dan tidak menerapkannya dirumah untuk menjaga kesehatannya beserta keluarganya pada masa pandemi covid-19. Namun lebih rendah dibanding dengan penelitian yang dilakukan oleh Puspasari \& Andriani (2017) di Kecamatan Bantarkalong Tasikmalaya menunjukkan bahwa ibu berpengetahuan kurang sebesar 65,2\%. Sedangkan penelitian yang dilakukan oleh Yoga (2020) di Posyandu Desa Segarajaya di Masa Pandemi menunjukkan bahwa pengetahuan yang kurang mengenai gizi sebanyak 57 responden atau 41,9\%

Pengetahuan muncul ketika seseorang menggunakan akal budinya untuk mengenali benda atau kejadian tertentu yang belum pernah dilihat atau dirasakan sebelumnya. Misalnya ketika seseorang mencicipi masakan yang baru dikenalnya, ia akan mendapatkan pengetahuan tentang bentuk, rasa, dan aroma masakan tersebut (Oktaviani, 2018).

Kurang dari setengah ibu balita di Posyandu Blok Cipeucang II Desa Talagawetan UPTD Puskesmas Talaga Kabupaten Majalengka adalah berpengetahuan kurang baik. Maka upaya petugas kesehatan yaitu perlu meningkatkan edukasi atau penyuluhan kepada ibu tentang gizi pada balita dengan cara yang lebih 
JOURNAL OF MIDWIFERY CARE :

VOL. 02 No. 01, DESEMBER 2021

DOI: $\underline{10.34305 / J M C . V 2 I 01.356}$ menarik seperti dengan poster dan metode demonstrasi cara menyajikan makanan yang bergizi dan seimbang. Bagi ibu yang mempunyai anak balita agar membawa ke posyandu, serta memberi makan pada anaknya sesuai dengan jadwal, jenis dan jumlah dengan menu yang bergizi dan seimbang.

Berdasarkan hasil penelitian menunjukkan bahwa ada hubungan pengetahuan Ibu dengan Status Gizi Balita pada Masa Pandemi Covid-19 di Posyandu Blok Cipeucang II Desa Talagawetan UPTD Puskesmas Talaga Kabupaten Majalengka tahun 2021 ( $(v a l u e=0,037$ ). Adanya hubungan hal ini dapat dikarenakan pengetahuan ibu yang baik tentang gizi akan melahirkan pemahaman dan tindakan yang baik pula dalam pemenuhan gizi pada anaknya.

Hasil penelitian ini sejalan dengan penelitian Puspasari \& Andriani (2017) di Kecamatan Bantarkalong Tasikmalaya menunjukkan bahwa ada hubungan antara pengetahuan ibu tentang gizi dan asupan makan balita dengan status gizi balita usia 12-24 bulan. Juga penelitian Susilowati \& Himawati (2017) di Wilayah Kerja Puskesmas Gajah 1 Demak menunjukkan bahwa ada hubungan tingkat pengetahuan ibu tentang gizi balita dengan status gizi balita. Demikian juga dengan penelitian yang dilakukan oleh Harikatang \& Mardiyono (2020) di Tangerang menunjukkan bahwa ada hubungan antara pengetahuan ibu dengan gizi balita pada masa pandemi Covid-19.

Hasil penelitian ini sejalan dengan teori bahwa pengetahuan tentang gizi sangat diperlukan agar dapat mengatasi masalah-masalah yang timbul akibat konsumsi gizi. Wanita khususnya ibu sebagai orang yang bertanggung jawab terhadap konsumsi makanan bagi keluarga. Ibu harus memiliki pengetahuan tentang gizi baik diperoleh melalui pendidikan formal maupun non formal (Kementrian Kesehtan RI, 2019) (Kementerian Kesehatan RI, 2018). Seorang ibu rumah tangga harus memiliki pengetahuan dalam menyusun dan menilai hidangan yang memenuhi syarat gizi, agar balita yang akan mengkonsumsinya tertarik serta pertumbuhan dan perkembangannya baik (Hidayat, 2018).

Hasil penelitian ini sejalan dengan teori bahwa menyusun dan menilai hidangan merupakan pengetahuan dan keterampilan dasar yang diperlukan oleh semua orang, terutama mereka yang 
JOURNAL OF MIDWIFERY CARE :

VOL. 02 No. 01, DESEMBER 2021

DOI: $\underline{10.34305 / J M C . V 2 I 01.356}$ bertanggung jawab atas pengurusan dan penyediaan makanan, baik bagi keluarga maupun bagi berbagai institusi seperti asrama, wisma dan sebagainya yang harus menyediakan makanan bagi sejumlah atau sekelompok orang. Seorang ibu rumah tangga yang bukan ahli gizi, juga harus dapat menyusun dan menilai hidangan yang akan disajikan kepada anggota keluarganya (Sulistyoningsih, 2020).

Terdapat hubungan pengetahuan Ibu dengan Status Gizi Balita pada Masa Pandemi Covid-19 di Posyandu Blok

\section{Kesimpulan}

1. Sebagian kecil $(21,1 \%)$ status gizi balita pada masa pandemi Covid-19 di Posyandu Blok Cipeucang II Desa Talagawetan UPTD Puskesmas Talaga Kabupaten Majalengka adalah gizi kurang.

2. Kurang dari setengah $(33,3 \%)$ ibu balita di Posyandu Blok Cipeucang II Desa Talagawetan UPTD Puskesmas Talaga Kabupaten Majalengka adalah berpengetahuan kurang baik.

3. Ada hubungan pengetahuan Ibu dengan Status Gizi Balita pada Masa Pandemi Covid-19 di Posyandu Blok Cipeucang II Desa Talagawetan
Cipeucang II Desa Talagawetan UPTD Puskesmas Talaga Kabupaten Majalengka. Maka dari itu, ibu balita perlu meningkatkan pengetahuannya tentang gizi pada balita dengan cara aktif mencari informasi ke berbagai media yang dapat ibu akses atau berkonsultasi kepada petugas kesehatan. Bagi petugas kesehatan perlunya memberikan edukasi atau penyuluhan kepada ibu balita melalui kegiatan di posyandu dengan memperhatikan protokol kesehatan

Covid-19.

UPTD Puskesmas Talaga Kabupaten Majalengka tahun 2021 (〉 value = 0,037).

\section{Saran}

Posyandu agar bisa melaksanakan kegiatan posyandu sesuai dengan protokol kesehatan Covid-19, menyediakan sarana cuci tangan dan alat pengukur suhu bagi yang berkunjung ke posyandu. Upaya untuk mencegah gangguan gizi pada balita, maka petugas kesehatan bekerja sama dengan kader untuk melaksanakan kegiatan posyandu secara rutin setiap bulan, memotivasi ibu untuk membawa anaknya ditimbang ke posyandu, memberikan 
JOURNAL OF MIDWIFERY CARE :

VOL. 02 No. 01, DESEMBER 2021

DOI: $10.34305 / \mathrm{JMC} . \mathrm{V} 2 \mathrm{I} 01.356$ penyuluhan kepada ibu untuk memberikan makanan kepada anak sesuai jumlah, jadwal

\section{Daftar Pustaka}

Akbar, D. M., \& Aidha, Z. (2020). Perilaku Penerapan Gizi Seimbang Masyarakat Kota Binjai Pada Masa Pandemi

Covid-19 Tahun 2020. Jurnal Menara Medika.

Ariesta, M. (2020). Analisis Pengetahuan dan Sikap Ibu Tentang Gizi Terhadap Pencegahan Stunting Pada Anak Di Masa Pandemi Covid -19 Di Kelurahan Korong Gadang. Jurnal Ilmiah Cerebral Medika, 2, 2020.

Hidayat, A. A. (2018). Pengantar Ilmu Kesehatan Anak. PT. Rineka Cipta.

Kementerian Kesehatan RI. (2018). Buku Saku Pemantauan Status Gizi. Kementerian Kesehatan RI.

Kementerian Kesehatan RI. (2020a). Gugus Tugas Percepatan Penanganan Covid19. Kementerian Kesehatan RI.

Kementerian Kesehatan RI. (2020b). Profil Kesehatan Indonesia Tahun 2019. Kementrian Kesehatan RI.

kementrian kesehtan RI. (2019). Profil kesehatan Indonesia tahun 2018. Kementrian Kesehatan RI.

Oktaviani. (2018). Pengantar Ilmu Sosial. PT. Rosdakarya. dan jenisnya.

Dinas Kesehatan Kabupaten Majalengka. (2020). Data Covid-19 di Kabupaten Majalengka. Dinas Kesehatan Kabupaten Majalengka.

Hardinsyah, \& Supariasa, I. D. N. (2016). Ilmu Gizi Teori \& Aplikasi. In Buku Kedokteran ECG.

Harikatang, M. R., \& Mardiyono, M. M. (2020). Hubungan Pengetahuan dan Sikap Ibu dengan Gizi Balita di Satu Kelurahan di Tangerang. Jurnal Mutiara Ners Bulan. Amerta Nutrition.

https://doi.org/10.20473/amnt.v1i4.71 36

Puspasari, N., \& Andriani, M. (2017). Hubungan Pengetahuan Ibu tentang

Sulistyoningsih, H. (2020). Prosiding Seminar Nasional Kesehatan "Peran Tenaga Kesehatan Dalam Menurunkan Kejadian Stunting. Jurnal Seminar Nasional.

Susilowati, E., \& Himawati, A. (2017). Hubungan Tingkat Pengetahuan Ibu tentang Gizi Balita dengan Status Gizi Balita di Wilayah Kerja Puskesmas Gajah 1 Demak. Jurnal Kebidanan, 6(13), 21-25.

United Nations Children's Fund. (2017). Adolescents and Young People UNICEF DATA. United Nations Children's Fund.

Yoga, T. I. (2020). Pengetahuan Ibu 
JOURNAL OF MIDWIFERY CARE :

VOL. 02 NO. 01, DESEMBER 2021

DOI: $\underline{10.34305 / \mathrm{JMC} . \mathrm{V} 2 \mathrm{I} 01.356}$

Tentang Stunting Pada Balita Di

Posyandu Desa Segarajaya.
Ciptaan disebarluaskan di bawah

Lisensi Creative Commons

Atribusi-NonKomersial-

BerbagiSerupa 4.0 Internasional. (c) (i) (2)

Indonesian Journal of Health Development. 